\section{Myrica gale 'Lowboy': A Compact, Male, Sweetgale Plant with Southern Provenance}

\author{
Jessica D. Lubell-Brand and Mark H. Brand \\ Department of Plant Science and Landscape Architecture, University of \\ Connecticut, 1376 Storrs Road, Storrs, CT 06279-4067
}

Additional index words. alternatives to invasive plants, landscape adaptability, low maintenance, North American native shrub

Myrica gale (sweetgale) is a cold hardy (USDA hardiness zone 2) plant native to the northern latitudes of the northern hemisphere. In North America, the native range is from the northeastern United States west to the Great Lake states, and in the Pacific Northwest north to Alaska (U.S. Department of Agriculture-Natural Resources Conservation Service, 2021). A small population was reported in one county of North Carolina, but its continued existence is questioned beyond 2018 (LeGrand et al., 2021). Myrica gale is also native throughout Canada, Russia, Japan, North Korea, and northern Europe. It is an obligate wetland species (U.S. Department of Agriculture-Natural Resources Conservation Service, 2021) and is found almost exclusively at the edges of water bodies such as lakes, backwaters of slow rivers, acidic ponds, swamps, and bogs. Myrica gale is an upright, spreading, mounded, low-growing deciduous shrub (Dirr, 2009). Plants can be rhizomatous, but do not spread aggressively. In full sun, plants are typically $1 \mathrm{~m}$ tall, but may reach heights and widths of 1.2 to $1.5 \mathrm{~m}$. Leaves are simple and alternate, although the arrangement of the leaves on the stem creates a whorled appearance on vertical shoots. Myrica gale is a dioecious species, with male plants producing short catkins and female plants producing fruit that are nutlets. Myrica gale is a member of the Myriaceae, a family known for tolerance to wet, acidic, infertile, sandy soils and for its ability to fix nitrogen through root nodule associations with actinorhizal bacteria.

Myrica gale 'Lowboy' exhibits a more compact, dense, and uniform habit than is typical for the species. It derives from the southern part of the species' natural range, making it adaptable to landscape use, where temperatures are often warmer than those of natural areas. The plant performed well when tested in the challenging conditions of parking lot islands (Lubell, 2013). These characteristics will make this particular

Received for publication 19 May 2021. Accepted for publication 7 July 2021

Published online 3 September 2021.

This work was supported by the U.S. Department of Agriculture, National Institute of Food and Agriculture, Hatch Project, accession no. 1020832. J.D.L.-B. is the corresponding author. E-mail: Jessica.lubell@uconn.edu.

This is an open access article distributed under the CC BY-NC-ND license (https://creativecommons. org/licenses/by-nc-nd/4.0/). selection desirable for the ornamental landscape industry, which is in the process of bringing many North American native plants to market in the form of cultivated varieties (cultivars). In addition, this plant propagates easily from softwood stem cuttings and grows rapidly to a marketable plant in nursery container production.

\section{Origin}

'Lowboy' was selected from a group of seedlings germinated in 2010. The seed was
Fig. 1. Low-mounded habit of Myrica gale 'Lowboy'. produced by crossing a male and female clone of $M$. gale in the greenhouse in Spring 2009. Both parental genotypes were grown from cuttings collected from plants found growing in Mansfield, CT, in the southern part of the species' natural range. The decision was made to name this selection in 2016 after 6 years of evaluation.

\section{Description}

'Lowboy' grows 0.5 to $1 \mathrm{~m}$ tall, with similar width. Plants are densely branched with a spreading, mounded habit (Fig. 1). 'Lowboy' is a male genotype that produces amber-color catkins [Royal Horticultural Society (RHS) 177D] (Royal Horticultural Society and Flower Council of Holland, 1986) and are quite attractive on plants in early spring (Fig. 2). Leaves are narrow $(1.25-2 \mathrm{~cm}$ wide), oblanceolate to obovate (4-6 cm long), toothed at the ends, and are a bluish-green color (close to RHS 131A, 139A, and 147A) on the adaxial surface and a frosty lime-green color (RHS 137C) on the abaxial surface (Fig. 3). The foliage is aromatic when crushed or on hot days. Stems are a dark purple-brown (RHS 177A) with cream-color lenticels (RHS 158B; Fig. 4).
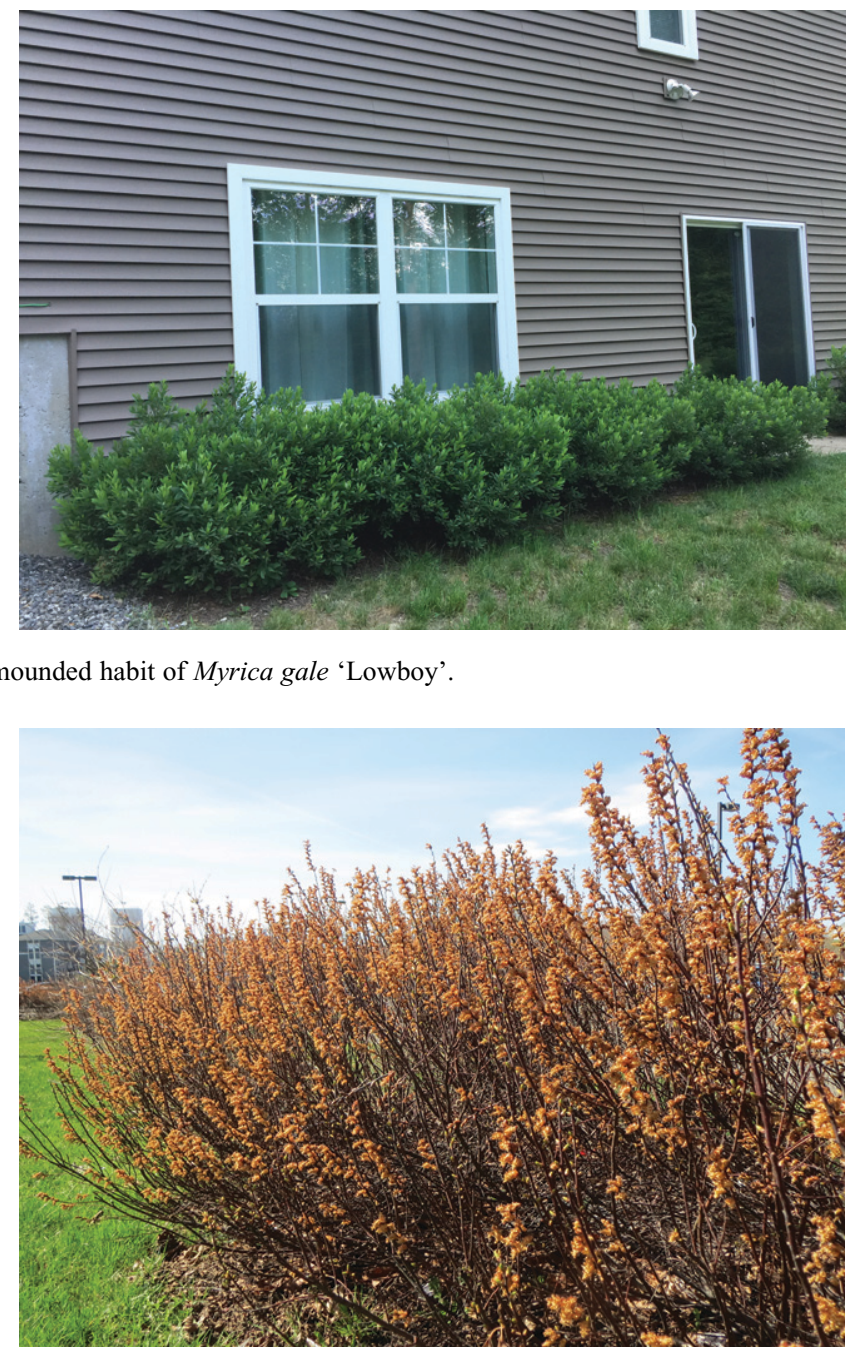

Fig. 2. Showy male flowers of Myrica gale 'Lowboy' in early spring. 


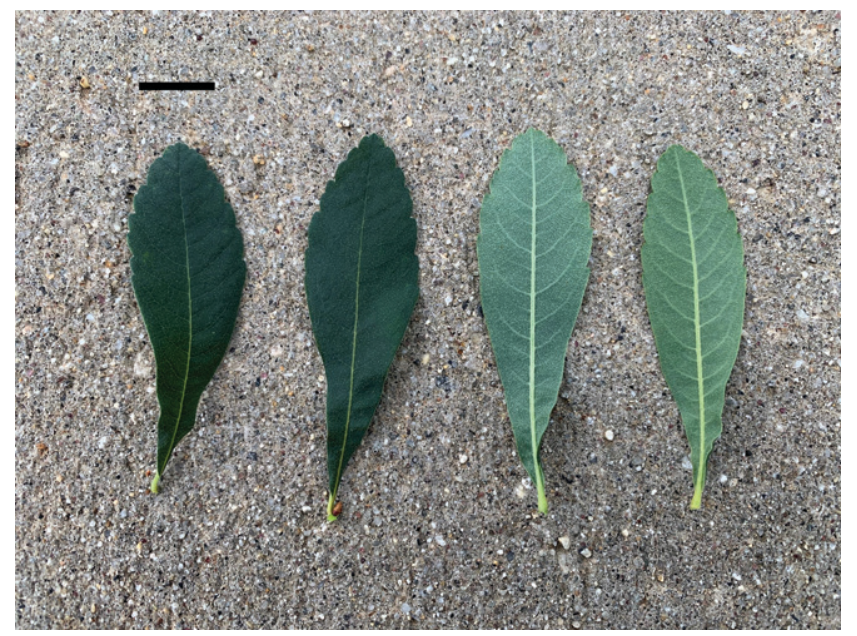

Fig. 3. Myrica gale 'Lowboy' leaves in summer. The left two leaves have an adaxial surface and the right two leaves have an abaxial surface. Scale bar $=1 \mathrm{~cm}$.

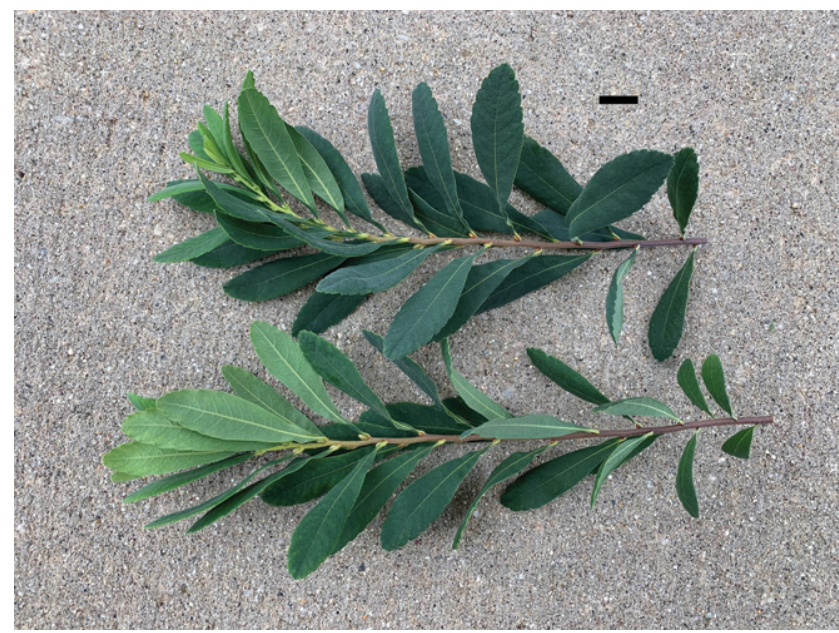

Fig. 4. Myrica gale 'Lowboy' stems and leaves in summer. Scale bar $=1 \mathrm{~cm}$.

There is a high demand for native plants such as 'Lowboy' for native landscaping. Despite $M$. gale growing naturally in moist soils, 'Lowboy' is adaptable to average garden soils as long as they are not excessively droughty. 'Lowboy' can be used in groups or mass plantings, or as a low hedge for formal landscapes. 'Lowboy' exhibits drought tolerance once established and performed well in trials from 2010 to 2013 designed to evaluate native shrubs for their ability to withstand harsh cultivated conditions such as compacted, infertile soil; full sun; wind; and pedestrian traffic (Lubell, 2013). Multiple plants of 'Lowboy' were evaluated in a residential landscape planting from 2012 to 2021, where it performed well as a foundation plant as a result of its compact size and ability to tolerate average to seasonally dry soils and reflected light from a structure.
Propagation, Production, and Landscape Maintenance

'Lowboy' is easy to propagate from softwood stem cuttings to achieve $\geq 80 \%$ success. Cuttings 7 to $10 \mathrm{~cm}$ in length should be collected in mid-June to mid-July and treated with 1000 to $3000 \mathrm{ppm}$ indole-butyric acid in talc. Cuttings root in 25 to $35 \mathrm{~d}$ and, once rooted, can be potted and fertilized, and will produce a new flush of growth. Rooted cuttings overwinter easily. Plants grow well in standard nursery media consisting of partially aged pine bark, peatmoss, and sand (4:2:1), with low recommended rates of controlledrelease fertilizer. From a rooted cutting, salable trade no. 1 container plants may be produced in 1 year, and salable trade no. 3 plants in 2 years. 'Lowboy' is low maintenance and requires only occasional removal of old or damaged shoots. Plants respond well to shearing to achieve even greater size control and can be rejuvenated by cutting plants to the ground. Plants are not affected significantly by pest or disease problems either in production or in the landscape.

\section{Availability}

'Lowboy' will be marketed as NativeStar ${ }^{\circledR}$ Lowboy sweetgale. It is currently being produced by Prides Corner Farms, Lebanon, CT. Inquiries for plant material should be made to Jessica D. Lubell-Brand, Department of Plant Science and Landscape Architecture, University of Connecticut.

\section{Literature Cited}

Dirr, M.A. 2009. Manual of woody landscape plants: Their identification, ornamental characteristics, culture, propagation and uses. 6th ed. Stipes Publishing, Champaign, IL.

LeGrand, H., B. Sorrie, and T. Howard. 2021. Vascular plants of North Carolina. Raleigh (NC): North Carolina Biodiversity Project and North Carolina State Parks. 2 July 2021. <https://auth1.dpr.nc parks.gov/flora/species_account.php?id=1949> .

Lubell, J.D. 2013. Evaluating landscape performance of six native shrubs as alternatives to invasive exotics. HortTechnology 23:119-125, doi: https://doi.org/10.21273/HORTTECH.23.1.119.

Royal Horticultural Society and Flower Council of Holland. 1986. Royal Horticultural Society colour chart. Royal Horticultural Society, London, U.K.

U.S. Department of Agriculture-Natural Resources Conservation Service. 2021. The PLANTS database. 29 June 2021. < http://plants.usda.gov>. 